ol 1, No. 1 (2020), June 2020

E-ISSN: 2746-2471

\title{
PERBEDAAN MOTIVASI INTERNAL DAN EKSTERNAL TERHADAP MINAT TEKNOPRENEUR MAHASISWA INFORMATIKA
}

\author{
Berta Dian Theodora \\ Program Studi Informatika \\ Universitas Indraprasta PGRI
}

\section{Berta.dtos@gmail.com}

\begin{abstract}
ABSTRAK
Ketika semua lulusan bergantung pada sektor usaha yang telah ada akan menjadi beban perkembangan ekonomi namun dengan kemampuan setiap individu yang berbeda-beda merupakan peluang tidak terbatas bagi dirinya untuk menjadikan kemampuan tersebut menjadi sumber pendapatan. Beberapa universitas telah memasukan matakuliah kewirausahaan dikurikukulum akan tetapi pembelajaran kewirausahaan berfokus pada menciptakan wirausaha secara umum, belum berfokus untuk mengkaitkan keilmuan utama dan peluang usaha. Penguasaan teknologi bagi peserta didik berlatarbelakang informatika merupakan modal daya saing yang kuat terutama di era industri 4.0. Seorang wirausaha akan menggunakan apa yang dimiliki sebagai modal usahanya, bagi lulusan teknologi informasi, manajemen informasi dan informatika dapat menggunakan ilmu mereka dalam dunia usaha, sektor yang menggabungkan kedua hal tersebut dikenal dengan nama teknopreneur. Tujuan penelitan adalah untuk mengetahui perbedaan pengaruh dari motivasi internal dan eksternal terhadap minat teknopreneur mahasiswa. Sampel berjumlah 200 adalah mahasiswa berlatarbelakang informatika dan telah mengikuti pembelajaran kewirausahaan. Analisis mengunakan pendekatan kuantitatif dengan metode Anova dua arah dengan interaksi Hasil penelitian menunjukan bahwa terhadap perbedaan pengaruh ketika kondisi motivasi internal tinggi atau rendah terhadap minat teknopreneur. Terdapat perbedaan pengaruh ketika kondisi motivasi eksternal tinggi atau rendah terhadap minat teknopreneur, namun tidak terjadi interaksi antara motivasi internal dan eksternal

Kata Kunci : teknopreneur, minat, motivasi
\end{abstract}

\section{A. PENDAHULUAN}

Lingkungan pendidikan merupakan tempat dimana seorang individu mendapatkan pengetahuan sehingga terciptalah sebuah ketertarikan pada suatu subjek tertentu. Undangundang mengenai sistem pendidikan nasional yaitu UU no.20 tahun 2003 tepatnya pada pasal 1 ayat 1 menyatakan bahwa pendidikan adalah usaha sadar dan terencana untuk mewujudkan suasana belajar dan proses pembelajaran agar peserta didik secara aktif mengembangkan potensi dirinya untuk memiliki kekuatan spiritual, keagamaan, pengendalian diri, kepribadian, kecerdasan, akhlak mulia serta keterampilan yang diperlukan dirinya, 
masyarakat, bangsa dan negara. Pasal tersebut mengharapkan lingkungan sekolah dimana para peserta didik mendapatkan pengetahuan akan memberikan bekal guna menjawab tantangan jaman.

Badan Pusat Statistik (BPS) mencatat selama tiga tahun terakhir jumlah pengangguran lulusan universitas terus bertambah terlihat pada tabel 1. Kondisi ketenagakerjaan menjadi salah satu faktor yang perlu diperhatikan oleh kalangan pendidik, perubahan dalam dunia kerja menjadi pertimbangan dalam menyusun kurikulum pendidikan. Penyerapan tenaga kerja pada setiap tingkatan pendidikan yang lambat menjadi gambaran belum sesuainya ilmu yang didapatkan oleh peserta didik dengan kebutuhan dunia kerja. Namun jika semua lulusan bergantung pada sektor usaha yang telah ada akan terus menjadi beban perkembangan ekonomi.

Tabel 1

Jumlah penggangguran berdasarkan Pendidikan Tertinggi yang Ditamatkan

\begin{tabular}{|l|r|r|r|}
\hline \multirow{2}{*}{\multicolumn{1}{|c|}{ Satuan Pendidikan }} & \multicolumn{3}{c|}{ Tahun ( per Februari) } \\
\cline { 2 - 4 } & \multicolumn{1}{c|}{2017} & \multicolumn{1}{c|}{2018} & \multicolumn{1}{c|}{2019} \\
\hline Tidak/belum pernah sekolah & 92.331 & 42.039 & 35.655 \\
\hline Tidak/belum tamat SD & 546.897 & 446.812 & 435.655 \\
\hline SD & 1.292 .234 & 967.630 & 954.010 \\
\hline SLTP & 1.281 .240 & 1.249 .761 & 1.219 .767 \\
\hline SLTA Umum/SMU & 1.552 .894 & 1.650 .636 & 1.680 .794 \\
\hline SLTA Kejuruan/SMK & 1.383 .022 & 1.424 .428 & 1.381 .964 \\
\hline Akademi/Diploma & 249.705 & 300.845 & 269.976 \\
\hline Universitas & 606.939 & 789.113 & 839.019 \\
\hline
\end{tabular}

Sumber : BPS.2020

Ketika para lulusan bergantung dengan usaha yang telah ada dalam jangka panjang akan meningkatkan persaingan untuk mendapatkan pekerjaan, dengan adanya globalisasi memungkinkan para pencari kerja dari luar wilayah atau bahkan luar negeri untuk memperoleh kesempatan bekerja tersebut. Peluang yang semakin terbatas menjadi alasan perlunya dilakukan perubahan pola pikir dari mencari kerja menjadi menciptakan lapangan pekerjaan dikalangan peserta didik. Wirausaha menjadi salah satu peluang untuk memiliki pendapatan dan pekerjaan tanpa bergantung dengan orang lain sekaligus menciptakan lapangan pekerjaan yang sesuai dengan kemampuan diri sendiri.

Kemampuan setiap individu yang berbeda-beda merupakan peluang tidak terbatas bagi dirinya untuk menjadikan kemampuan tersebut menjadi sumber pendapatan. Peningkatan kemampuan dengan menempuh jalur pendidikan diantaranya di universitas dengan ilmu yang lebih spesifik dibandingkan sekolah menengah. Kemampuan yang diperoleh menjadi bekal utama dalam membuka peluang menciptakan lapangan pekerjaan, sebagai contoh bagi 


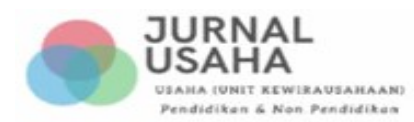

Vol 1, No. 1 (2020), June 2020

E-ISSN: 2746-2471

mereka yang mempelajari ilmu keguruan tidak hanya menggantungkan keadaan dengan melamar pekerjaan di sekolah-sekolah yang telah ada, namun bisa menyediakan les perorangan atau les berkelompok, bagi mereka dengan latar belakang olahraga bisa menjadi pelatih diunit kegiatan di sekolah tanpa menjadi guru disekolah tersebut atau membuka sasana olahraga bahkan bisa menjadi seorang konsultan olahraga.

Peluang untuk menjadi wirausaha terbuka lebar jika melihat kemampuan setiap individu yang unik dan berbeda, namun belum semua peserta didik memiliki pola pikir untuk menggunakan ilmu yang mereka peroleh di universitas sebagai modal berwirausaha. Sangat disayangkan ketika peserta didik telah menempuh pendidikan selama 4 tahun ditingkat universitas namun ilmu tersebut tidak diterapkan secara langsung. Beberapa universitas telah memberikan modal untuk menjadi seorang wirausaha dengan memasukan matakuliah kewirausahaan dikurikukulum akan tetapi pembelajaran kewirausahaan berfokus pada menciptakan wirausaha secara umum, belum berfokus untuk mengkaitkan keilmuan utama peserta didik dan peluang usaha.

Keilmuan teknologi informasi menjadi salah satu program studi yang menarik banyak peserta didik untuk bergabung sejalan dengan berkembangnya revolusi industri 4.0. Faktor teknologi menjadi salah satu kemampuan dasar yang perlu dimiliki oleh setiap peserta didik guna mengikuti revolusi industri 4.0, keadaan ini telah menuntut individu untuk menggunakan teknologi dalam setiap aspek keseharian diantaranya bidang komunikasi, ekonomi, transportasi dan kesehatan.

Penguasaan teknologi bagi peserta didik program studi teknologi informasi, manajemen informasi dan informatika merupakan modal daya saing yang kuat terutama di era industri 4.0. Seorang wirausaha akan menggunakan apa yang dimiliki sebagai modal usahanya, bagi lulusan teknologi informasi, manajemen informasi dan informatika dapat menggunakan ilmu mereka dalam dunia usaha, sektor yang menggabungkan kedua hal tersebut dikenal dengan nama teknopreneur.

Jumlah wirausaha terus meningkat setiap tahun, namun adakah tindakan yang dilakukan pihak lingkungan sekolah dalam hal ini pada tingkatan universitas dalam meningkatkan minat siswa pada program studi teknologi informasi, manajemen informasi dan informatika tidak hanya terbatas sebagai seorang wirausha namun sebagai sebagai teknopreneur.

\section{B. KAJIAN PUSTAKA}

Teknopreneur berasal dari gabungan dua buah kata yaitu technique yang berarti orang dengan kemampuan dibidang teknologi dan entrepreneur berarti orang dengan kemampuan membaca peluang untuk menghasilkan keuntungan, secara sederhana dapat diartikan teknopreneur adalah seorang dengan kemampuan teknologi dan memanfaatkannya untuk menangkap peluang guna mendapatkan keuntungan. Technopreneurship menurut Nelloh (2018) adalah sebuah proses pembentukan usaha baru yang melibatkan teknologi yang diharapkan dapat menciptakan strategi dan 


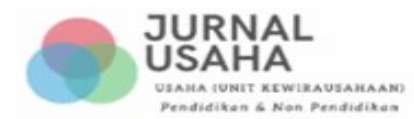

Vol 1, No. 1 (2020), June 2020

E-ISSN: 2746-2471

inovasi yang tepat dan menjadi salah satu faktor dalam mengembangkan ekonomi nasional.

Technopreneurship selain bermanfaat dalam industri besar dan canggih, namun dapat diarahkan untuk memberikan manfaaat kepada masyarakat khususnya mereka yang berada pada kondisi ekonomi kurang, dampak technopreneurship dalam sektor ekonomi adalah, menciptakan lapangan kerja baru, menggerakkan dan menciptakan peluang bisnis pada sektor-sektor ekonomi yang lain, dan meningkatkan efisiensi dan produktivitas, bahkan dengan luasnya wilayah Indonesia peluang mengembangkan technopreneurship untuk menciptakan nilai tambah khususnya bagi produk- produk pertanian, kehutanan, peternakan, dan perikanan masih terbuka luas.( Handrimurthahjo.2013; Baihaqi.2015).

Pendidikan kewirausaan yang dijelaskan Rasmussen, Moberg, \& Revsbech (2015) The four entrepreneurial dimensions (gambar 1) dapat dilakukan melalui beberapa kegiatan diantaranya 1) The action dimension will often take place in a context of outward orientation, where successful action in a particular context promotes competence in the action dimension, while also supporting knowledge of the world and influencing students' ways of observing and perceiving the world. 2) Positive experiences in the action dimension will, like other experiences of success, enhance students' belief in their ability to act in the world and thereby also their personal attitude. 3)Focus on the outward orientation dimension will encourage the development of divergent thinking, creativity and students' ability to identify opportunities in the world. 4)Personal attitude influences the actions students can and are willing to take and also how they perceive their opportunities in the world. 5)The development of creativity will affect students' perceived possibilities to act in the world and increase the likelihood of new ideas about the future for themselves and others.

Kodrat dan Christina (2015) mengemukakan bahwa untuk menciptkan entreprenur melalui pendidikan di Fakultas Ekonomi Universitas Ciputra dilakukan melalui tahapan: 1) membangkitkan inspirasi mahasiswa untuk menanamkan pola pikir, melatih kemampuan melihat peluang, kreativitas, dan mengkalkulasikan risiko, keterampilan memimpin dan mengembangkan jejaring bisnis mahasiswa (dilakukan pada semester 1 hingga semester 7). Pengembangan dan melatih kreativitas dapat dilakukan melalui 4P yaitu: 1) Pembentukan pribadi kreatif, 2) Motivasi Pendorong kreativitas, 3) Proses kreativitas, dan 4) Produk kreatif.

Badan pengkajian dan penerapan teknologi mendefinisikan teknopreneur sebagai seorang entrepreneur yang melibatkan teknologi dalam bisnisnya. Teknopreneur perlu memiliki beberapa hal untuk menjadi modal usaha, diantaranya : 1) Ide yang siap di eksplorasi, 2) softskill dan mindset, 3) Validasi ide, 4) pengembangan produk, 5) Pengetahuan tentang Hak Kekayaan Intelektual, 6) Model usaha, 7) Kemampuan analisis pasar, 8) Pengetahuan perencanaan usaha, 9) Pengetahuan keuangan dan 10) Kemampuan pemasaran. Karakter seorang teknopreneur yaitu 1) N-Ach (need of achievement) yang tinggi, 2) kemampuan 
Vol 1, No. 1 (2020), June 2020

E-ISSN: 2746-2471

konseptual dan pemecahan masalah yang tinggi, 3) wawasan dan cara berpikir yang luas, 4) percaya diri dan toleransi, 5) reaslistis, 6) moderate risks taker, 7) moderate interpersonal skill dan 8) sufficient emotional stability.

\section{METODE PENELITIAN}

Penelitian ini akan melihat perbedaan pengaruh dari faktor internal dan faktor eksternal terhadap minat teknopreneur mahasiswa, menggunakan pendekatan kuantitatif metode desain faktorial. Populasi penelitian adalah mahasiswa program studi informatika, pengambilan sampel menggunakan sampel acak sederhana, sebanyak 200 mahasiswa menjadi sampel penelitian.

Desain penelitian yang akan dilakukan adalah sebagai berikut :

Tabel 2

Desain Penelitian

\begin{tabular}{|c|c|c|c|}
\hline \multicolumn{2}{|c|}{ Variabel } & \multicolumn{2}{c|}{ Motivasi Eksternal } \\
\cline { 3 - 4 } & Tinggi & Rendah \\
\hline \multirow{2}{*}{$\begin{array}{c}\text { Motivasi } \\
\text { Internal }\end{array}$} & Tinggi & $\mathrm{MT}_{1}$ & $\mathrm{MT}_{2}$ \\
\cline { 2 - 4 } & Rendah & $\mathrm{MT}_{3}$ & $\mathrm{MT}_{4}$ \\
\hline
\end{tabular}

Sumber : Peneliti.2020

Keterangan :

$\mathrm{MT}_{1}$ : Rata-rata minat teknopreneur dengan motivasi eksternal tinggi dan motivasi internal tinggi

$\mathrm{MT}_{2}$ : Rata-rata minat teknopreneur dengan motivasi eksternal rendah dan motivasi internal tinggi

$\mathrm{MT}_{3}$ : Rata-rata minat teknopreneur dengan motivasi eksternal tinggi dan motivasi internal rendah

$\mathrm{MT}_{4}$ : Rata-rata minat teknopreneur dengan motivasi eksternal rendah dan motivasi internal rendah

Instrument penelitian menggunakan kuesioner yang telah diuji validitas dan reliabilitasnya. Uji prasyarat yang akan dilakukan adalah uji Normalitas, uji linearitas, uji heteroskedatisitas dan uji multikolinearitas, setelah uji prasyarat diselesaikan maka akan dilakukan uji anova faktorial dengan interaksi.

\section{HASIL DAN PEMBAHASAN}

Tabel 3

One-Sample Kolmogorov-Smirnov Test

\begin{tabular}{|c|c|}
\hline Unstandardized \\
Residual \\
\hline
\end{tabular}


Vol 1, No. 1 (2020), June 2020

E-ISSN: 2746-2471

\begin{tabular}{|ll|r|}
\hline $\mathrm{N}$ & & 199 \\
Normal Parameters $^{\mathrm{a}, \mathrm{b}}$ & Mean & .0000000 \\
& Std. Deviation & 2.75691015 \\
Most Extreme & Absolute & .054 \\
Differences & Positive & .054 \\
& Negative & -.036 \\
Test Statistic & & .054 \\
Asymp. Sig. (2-tailed) & & $.200^{\mathrm{c}, \mathrm{d}}$ \\
\hline
\end{tabular}

Uji normalitas pada tabel 3 memiliki nilai sig 0,200 >0,05 sehingga dapat diartikan bawah data berdistribusi normal

Tabel 4

ANOVA Table

\begin{tabular}{|c|c|c|c|c|c|c|c|}
\hline & & & $\begin{array}{l}\text { Sum of } \\
\text { Squares }\end{array}$ & df & $\begin{array}{c}\text { Mean } \\
\text { Square }\end{array}$ & $\mathrm{F}$ & Sig. \\
\hline \multirow{5}{*}{$\begin{array}{l}\text { minat * } \\
\text { internal }\end{array}$} & Between & (Combined) & 1060.500 & 22 & 48.205 & 5.983 & .000 \\
\hline & Groups & Linearity & 865.661 & 1 & 865.661 & 107.451 & .000 \\
\hline & & $\begin{array}{l}\text { Deviation from } \\
\text { Linearity }\end{array}$ & 194.839 & 21 & 9.278 & 1.152 & .300 \\
\hline & \multicolumn{2}{|c|}{ Within Groups } & 1417.912 & 176 & 8.056 & & \\
\hline & \multicolumn{2}{|l|}{ Total } & 2478.412 & 198 & & & \\
\hline
\end{tabular}

Tabel 5

ANOVA Table

\begin{tabular}{|c|c|c|c|c|c|c|c|}
\hline & & & $\begin{array}{l}\text { Sum of } \\
\text { Squares }\end{array}$ & $\mathrm{df}$ & $\begin{array}{l}\text { Mean } \\
\text { Square }\end{array}$ & $\mathrm{F}$ & Sig. \\
\hline \multirow{5}{*}{$\begin{array}{l}\text { minat * } \\
\text { eksternal }\end{array}$} & Between & (Combined) & 1060.376 & 28 & 37.871 & 4.533 & .000 \\
\hline & Groups & Linearity & 716.531 & 1 & 716.531 & 85.766 & .000 \\
\hline & & $\begin{array}{l}\text { Deviation from } \\
\text { Linearity }\end{array}$ & 343.845 & 27 & 12.735 & 1.524 & .057 \\
\hline & \multicolumn{2}{|c|}{ Within Groups } & 1428.619 & 171 & 8.354 & & \\
\hline & \multicolumn{2}{|l|}{ Total } & 2488.995 & 199 & & & \\
\hline
\end{tabular}

Berdasarkan hasil uji linearitas dengan melihat nilai sig pada deviation from linearity, disimpulkan terdapat hubungan linear antara internal terhadap minat (tabel 4) dengan nilai sig 0,300 >0,05 dan eksternal terhadap minat (tabel 5) dengan nilai sig $0,057>0,050$ 
Tabel 6

Coefficients $^{\mathrm{a}}$

\begin{tabular}{|ll|r|r|r|r|r|}
\hline \multirow{2}{*}{} & \multicolumn{2}{|c|}{$\begin{array}{c}\text { Unstandardized } \\
\text { Model }\end{array}$} & \multicolumn{1}{c|}{$\begin{array}{c}\text { Standardized } \\
\text { Coefficients }\end{array}$} & \multicolumn{1}{c|}{$\mathrm{t}$} & \multicolumn{1}{c|}{ Sig. } \\
\cline { 2 - 7 } & \multicolumn{1}{|c|}{$\mathrm{B}$} & \multicolumn{1}{c|}{ Std. Error } & \multicolumn{1}{c|}{ Beta } & & \\
\hline 1 & (Constant) & -1.905 & 1.352 & & -1.409 & .161 \\
& internal & .048 & .028 & .154 & 1.714 & .088 \\
& eksternal & .021 & .025 & .077 & .859 & .392 \\
\hline
\end{tabular}

a. Dependent Variable: abs_res1

Uji gletser dipakai untuk melakukan uji heteroskedatisitas, berdasarkan hasil yang diperoleh (tabel 6) nilai sig internal 0,088 > 0,05 dan nilai sig eksternal $0,392>0,05$ sehingga dapat disimpulkan bahwa tidak terjadi heteroskedatisitas pada variabel internal dan eksternal

Tabel 7

Coefficients $^{\mathrm{a}}$

\begin{tabular}{|c|c|c|c|c|c|c|c|}
\hline \multirow[b]{2}{*}{ Model } & \multicolumn{2}{|c|}{$\begin{array}{c}\text { Unstandardized } \\
\text { Coefficients }\end{array}$} & \multirow{2}{*}{$\begin{array}{l}\text { Standardized } \\
\text { Coefficients } \\
\text { Beta }\end{array}$} & \multirow[t]{2}{*}{$t$} & \multirow[t]{2}{*}{ Sig. } & \multicolumn{2}{|c|}{$\begin{array}{c}\text { Collinearity } \\
\text { Statistics }\end{array}$} \\
\hline & $\mathrm{B}$ & Std. Error & & & & Tolerance & VIF \\
\hline $1 \quad$ (Constant) & 4.088 & 2.247 & & 1.819 & .070 & & \\
\hline internal & .273 & .046 & .422 & 5.901 & .000 & .605 & 1.654 \\
\hline eksternal & .153 & .041 & .268 & 3.748 & .000 & .605 & 1.654 \\
\hline
\end{tabular}

a. Dependent Variable: minat

Kesimpulan dari uji multikolinearitas terlihat pada tabel 7 dengan nilai Tolerance sebesar $0,605>0,10$ dan nilai VIF $1,654<10,00$ sehingga dapat dikatakan bahwa tidak terdapat multikolinearitas antar variabel.

Tabel 8 
Vol 1, No. 1 (2020), June 2020

E-ISSN: 2746-2471

Tests of Between-Subjects Effects

Dependent Variable: Minat tinggi dan rendah

\begin{tabular}{|l|r|r|r|r|r|}
\hline Source & $\begin{array}{c}\text { Type III } \\
\text { Sum of } \\
\text { Squares }\end{array}$ & df & $\begin{array}{c}\text { Mean } \\
\text { Square }\end{array}$ & \multicolumn{1}{|c|}{ F } & Sig. \\
\hline Corrected & $775.376^{\mathrm{a}}$ & 3 & 258.459 & 29.562 & .000 \\
Model & 129766.692 & 1 & 129766.692 & 14842.434 & .000 \\
Intercept & 381.734 & 1 & 381.734 & 43.662 & .000 \\
Internal & 67.770 & 1 & 67.770 & 7.751 & .006 \\
eksternal & .884 & 1 & .884 & .101 & .751 \\
Internal * & 1713.619 & 196 & 8.743 & & \\
eksternal & 173543.000 & 200 & & & \\
Error & 2488.995 & 199 & & & \\
Total & & & & \\
Corrected Total & & & & \\
\hline
\end{tabular}

a. $\mathrm{R}$ Squared $=.312$ (Adjusted $\mathrm{R}$ Squared $=.301)$

Hasil Uji Anova dengan interaksi terlihat pada tabel 8 dan berdasarkan nilai sig internal $0,000<0,05$ disimpulkan bahwa terdapat perbedaan minat teknopreneur bagi mereka yang memiliki motivasi internal tinggi dan rendah. Kondisi eksternal dengan nilai sig 0,006 $<0,05$ disimpulkan bahwa terdapat perbedaan minat teknopreneur bagi mereka yang memiliki motivasi eksternal tinggi dan rendah

Pengujian interaksi dilihat berdasrkan nilai sig internal*eksternal yaitu $0,751>0,05$ maka disimpulkan bahwa tidak ada interaksi motivasi internal dan eksternal dalam mempengaruhi minat teknopreneur

Tabel 9

Nilai Rata-rata Minat Teknopreneur Berdasarkan Kelompok

\begin{tabular}{|c|c|c|c|}
\hline \multicolumn{2}{|c|}{ Variabel } & \multicolumn{2}{c|}{ Motivasi Eksternal } \\
\cline { 3 - 4 } & Tinggi & 31,631 & Rendah \\
\hline Motivasi & Tinggi & 30,139 \\
\cline { 2 - 4 } Internal & Rendah & 28,300 & 27,144 \\
\hline
\end{tabular}

Sumber : Peneliti.2020

Tabel 9 menjelaskan secara umum rata-rata minat teknoprenuer mahasiswa yang dibedakan berdasarkan motivasi internal dan motivasi eksternal yang mempengaruhinya. Selisih nilai rata-rata minat teknopreneur mahasiswa dengan kondisi motivasi eksternal tinggi dan motivasi internal tinggi dibandingkan motivasi eksternal tinggi dan motivasi internal rendah adalah 2,331. Selisih nilai rata-rata minat teknopreneur mahasiswa dengan kondisi motivasi internal tinggi dan motivasi eksternal tinggi dibandingkan motivasi internal tinggi dan motivasi eksternal rendah adalah 1,492.

Ketika kondisi motivasi internal sama (tinggi) dengan kondisi motivasi eksternal berbeda (tinggi dan rendah) selisih yang didapat lebih sedikit dibandingkan selisih ketika kondisi motivasi eksternal (sama) dan kondisi motivasi internal berbeda (tinggi dan rendah). 


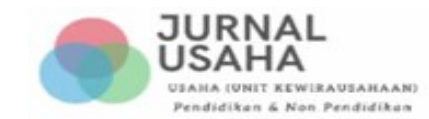

Vol 1, No. 1 (2020), June 2020

E-ISSN: 2746-2471

Dapat disimpulkan bahwa ketika perbedaan kondisi motivasi internal lebih mempengaruhi minat teknoprenuer dibandingkan motivasi eksternal.

Mata Kuliah Kewirausahaan yang diberikan masih bersifat umum, belum mengarahkan pada kewirausahaan berdasarkan bidang ilmu yaitu informatika, hal ini terlihat dari hasil uji interaksi yang menyatakan bahwa tidak terjadi interaksi antara motivasi internal dan eksternal, hasil ini terlihat pula pada penelitian Sumarno, Saryono dan Gimin (2017) dimana pengembangan kewirausahaan berjalan baik namun isi perkuliahan dan kegiatan belum mengarah kepada pengembangan teknopreneurship sehingga jumlah mahasiswa yang memiliki minat technopreneurship masih sangat sedikit.

Kebijakan dan kegiatan pendukung kewirausahaan penting untuk menghasilkan lulusan sebagai wirausahawan bahwa program pengembangan kewirausahaan diharapkan menjadi wahana pengintegrasian secara sinergi antara penguasaan sains dan teknologi dengan jiwa kewirausahaan (Galus.2009 ; Handrimurthahjo.2013). Perlu dipahami secara mendalam bahwa terdapat perbedaan antara teknopreneur dan entrepreneur, ketika seorang memiliki usaha dengan menjual dan mendapatkan profit maka orang tersebut dikenal dengan entrepreneur namun jika seseorang menggunakan teknologi sesuai dengan kebutuhan pelanggan yang ditargetkan sehingga pada akhirnya mendapatkan profit maka dikenal sebagai seorang teknopreneur.

\section{E. SIMPULAN DAN SARAN}

Kondisi motivasi internal dan eksternal mahasiswa akan mendatangkan perbedaan terhadap minat teknopreneurship mereka. Sedangkan selama penelitian dilangsungkan mahasiswa merasa tidak adanya interaksi antara motivasi internal yang mereka miliki dengan motivasi dari luar (eksternal) terhadap minat teknopreneur. Tidak terdapatnya interaksi ini perlu mendapatkan perhatian lebih dari pihak penyelenggara pendidikan, karena setelah menerima pembelajaran selama satu semester belum terdapat interaksi antara lingkungan dan kepribadian mahasiswa.

Penelitian ini memiliki keterbatasan diantaranya motivasi internal yang diukur terbatas pada motivasi berprestasi dan efikasi diri, sehingga perlu ditambahkan indikator lain. Keterbatasan pada motivasi eksternal adalah kondisi pembelajaran yang diterima mahasiswa dilingkungan universitas, diharapkan peneliti selanjutnya dapat menambahkan indikator lain pada motivasi eksternal seperti keterlibatan orang tua, lingkungan dan teman sebaya.

\section{DAFTAR PUSTAKA}

Badan Pengkajian dan Penerapan Teknologi. 2010. Pengembangan Kurikulum 
Vol 1, No. 1 (2020), June 2020

E-ISSN: 2746-2471

Teknopreneurship di Perguruan Tinggi. Jakarta : BPPT.

BPS. 2020. Tingkat Pengangguran Terbuka (TPT) Menurut Pendidikan Tertinggi yang Ditamatkan. Semarang: BPS

Handrimurthahjo, A. D. (2013) Model Pembelajaran Kewirausahaan di Perguruan Tinggi. Jurnal Universitas Paramadina Vol. 10 No. 2 Agustus 2013, hal 729-755.

Baihaqi, M. N. I (2015). Lembaga Pengembangan Pendidikan, Kemahasiswaan dan Hubungan Alumni (LP2KHA) Institut Teknologi Sepuluh Nopember (ITS) Surabaya.

Kodrat, D. S. dan Christina, W. (2015). Entrepreneurship: sebuah ilmu. Jakarta: Penerbit Erlangga.

Nelloh, L. A. M. (2018). Proses Kewirausahaan dalam Motivasi Pencapaian dan Intensi "EPreneurs" Mahasiswa Bisnis dan Manajemen. Jurnal Kajian Ilmiah, 18(1).

Rasmussen, Anders; Moberg, Kåre dan Revsbech, Christine. 2015. A Taxonomy Of Entrepreneurship Education: Perspectives On Goals, Teaching And Evaluation. URL: http://eng.ffe- ye.dk/knowledge- centre/entrepreneurshipeducation/taxonomy.

Sumarno, Saryono dan Gimin. 2017. Pengembangan technopreneurship di Universitas Riau. Jurnal Pendidikan Ekonomi UM Metro V1 5 No 2 hal 85-94 